\title{
EFFECT OF BOVINE SERUM ADDED TO MATURATION MEDIUM ON IN VITRO-MATURATION AND SOME GENES EXPRESSIONS OF BUFFALO OOCYTES
}

\author{
Sh.M. Shamiah, A. K. Kadoom * and A. F. Ashour \\ Animal Production Research Institute, Agriculture Research Center, Egypt. \\ ${ }^{*}$ Corresponding author E- mail. abkadoom@yahoo.com
}

\begin{abstract}
The effect of supplementing TCM-199 culture medium with bovine sera on buffalo's oocytes maturation in vitro and expression of some related genes were studied. A total 1149 immature buffalo oocytes were randomly divided into three groups, $G 1(n=315)$ were cultured in medium with no serum supplement(control), G2( $n=531)$ were cultured in medium supplemented with 10\% Fetal calf serum (FCS) and $G 3(n=303)$ were cultured in medium supplemented with $10 \%$ Estrous cow serum (ECS). After maturation, oocytes in each group were classified according to its shape and expansion into 2 subgroups, good (GO) and fair (FO) expanded oocytes. Expression of GAPDH, CX43, IGF II and $\beta$-Actin genes were studied in each subgroup. Results revealed that $G 3$ and $G 2$ showed high maturation rate $(P<0.01 \& 0.05$ respectively) compared to G1(control) and ECS was superior $(P<0.05)$ than FCS. The qualitative expression of genes under study showed no difference among the studied groups, except CX43 gene expression was missed in FO in G1 concluding that addition of bovine sera especially estrus cow serum enhance in vitro maturation of the buffalo oocytes and CX4 gene expression and further studies is needed to enhance the expression of CX43 gene which might help in increasing maturation rate.
\end{abstract}

Keywords: buffalo oocytes, IVM, gene expression, type of serum 


\section{INTRODUCTION}

Cumulus cells support and regulate oocyte development and maturation (Vozzi et al., 2001; Ward et al., 2002 and Xiang et al., 2010). Oocytes with many layers and compact cumulus oocyte complexes showed better in vitro maturation rate and blastocyst formation (Vanderhyden et al., 1992) compared to denuded ones. Under in vitro fertilization circumstances not all cultured oocytes undergo maturation and fertilization (IVM-IVF) due to incomplete maturation of oocytes during folliculogenesis (Sirard, 2001). The composition of maturation medium of in vitro maturation plays a significant role in the achievement of full developmental competence by oocytes (Kim et al., 2005 and Song et al., 2010). Maturation media are supplemented habitually with different types of blood serum like, bovine fetal serum; serum of cow in estrus; or albumin fraction V of bovine serum (Blanco and Simonetti, 2002). Estrus cow serum improves rate of maturation and the blastocyst formation compared to the use of fetal bovine serum (Hannelore et al., 2008), Moreover, presence of serum during culture period resulted in a significant increase in the level of gene expression of oxidative stress (MnSOD and SOX), apoptosis (Bax), differentiation (LIF) and implantation (RL-ß) (Rizos et al., 2003).

Oocyte growth is accompanied by cytoplasmic changes including mRNA transcription, protein translation and post translational modification (Sirard et al., 1989 and Kastrop et al.,1991). Gap junctions are thought to play a crucial role in regulating cell growth and development in various tissues, including ovaries (Herve et al., 2008 and Laws et al., 2008). One particular gap junction protein, which identified as connexin $43(\mathrm{Cx} 43)$ is found in granulosa cells. This protein 
contributes in embryonic and fetal development (Gershon et al., 2008). Expression of all mRNA transcript genes (Cx43, GDF 9, FGF-4 and Fibronectin) is positively correlated with cumulus expansion and polar body extrusion. Mitogenic lectin supplemented maturation media improves oocyte quality for in vitro embryo production (Pandey et al., 2009).

IGF-II is found to mediate growth in early mouse embryos and it forms a pathway in which imprinted genes affect development during pre-implantation stages (Rappolee et al., 1992). The transcript level of the insulin-like growth factor genes is significantly altered by in vitro culture condition (Pandey et al., 2010).

The aim of the present study is to clarify the effect of supplementing TCM-199 culture medium with bovine serum on buffalo's oocytes maturation and their relationship to some genes expressions that may affect the maturation process.

\section{MATERIALS AND METHODS}

This study was carried out at the International Livestock Management and Training Center, Animal Production Research Institute, Agric $\mu$ ltural Research Center, Ministry of Agric $\mu l t u r e$, Egypt. All chemicals used in this study were purchased from Sigma (Sant Luis, MO, USA), unless otherwise indicated.

\section{Oocyte recovery:}

Collected ovaries from slaughtered buffalo cows were placed in $\mathrm{NaCl}$ solution $(0.85 \mathrm{mg} / \mathrm{ml})$ containing antibiotics (penicillin, $100 \mathrm{iu} / \mathrm{ml}$ and streptomycin sulphate, $100 \mu \mathrm{g} / \mathrm{ml}$ ) and maintained at $25-30^{\circ} \mathrm{C}$ until oocyte recovery. The collected ovaries were washed twice in sterile 
freshly prepared saline. Oocytes were recovered from follicles with 2-8 $\mathrm{mm}$ in diameter by aspiration technique, using $10 \mathrm{ml}$ disposal plastic syringe attached to 18-gauge needle. The contents of syringe were placed slowly into $60 \mathrm{~mm}$ sterile Petri dish and examined under stereomicroscope for oocytes harvesting and evaluation. Oocytes having compact cumulus complex (COC) surrouding evenly granulated cytoplasm (more than three layers) were cultured after washing three times in sterile Dulbecco's phosphate buffer saline (DPBS) medium and finally with the maturation medium.

\section{Oocyte maturation:}

TCM-199 medium supplemented with $10 \mathrm{iu} / \mathrm{ml}$ PMSG (Gonaser, Laboratory Hipra, S.A.17170 Amer, spain), $20 \mathrm{iu} / \mathrm{ml} \mathrm{LH}$ as Chrionic gonadotropin (Pregnyl, The Nile company for pharmaceuticals and chemical industries, Cairo-ARE.R.C.C.115668), $1.0 \mu \mathrm{g} / \mathrm{ml}$ estradiol $\beta_{17}$ and $50 \mu \mathrm{g} / \mathrm{ml}$ Gentamycin sulfate with $\mathrm{pH}$ value of 7.3-7.4 and osmolarity of $280-300 \mathrm{mOsmol} / \mathrm{kg}$ was used for maturation of buffalo oocytes. COCs were divided into three groups. G1( $n=315)$ oocytes were cultured in TCM-199 without serum supplementation as( control). G2(n= 531) oocytes were cultured in TCM-199 with $10 \%$ fetal calf serum; FCS, while G3(n= 303) were cultured in TCM-199 with $10 \%$ estrus cow serum; ECS supplement. The three media were filtrated by $0.22-\mu \mathrm{m}$ millipore filter, A $500 \mu \mathrm{l}$ from each prepared maturation medium was placed into four well dishes and covered by $500 \mu \mathrm{l}$ sterile mineral oil and equilibriated in $\mathrm{CO}_{2}$ incubator $\left(5 \% \mathrm{CO}_{2}\right.$ at $38.5^{\circ} \mathrm{C}$ and high humidity) for 60 minutes. Thereafter, oocytes were transferred from washing medium to maturation medium. Then oocytes of the three groups were incubated for $24 \mathrm{hrs}$ (maturation period) in $5 \% \mathrm{CO}_{2} 5$ at $38.5^{\circ} \mathrm{C}$ and high humidity. 
After the maturation period, oocytes were classified under stereo microscope into good (GO) and fair (FO) according to cumulus expansion and darkness of their ooplasm. GO had good expanded cumulus cells and even ooplasm while FO had weak cumulus expansion, naked and/or had uneven dark ooplasm ,Shamia (2004). All oocytes were washed using PBS containing $1 \mathrm{mg} / \mathrm{ml}$ hyaluranidase to remove the cumulus cells, then, washed twice in PBS supplemented with 3\% BSA. Oocytes then either preserved in PBS at $-70 \stackrel{\circ}{\mathrm{C}}$ for RNA isolation (72 oocytes from all subgroups as 21 from G1, 33 from G2 and 18 from G3) or loaded on clean slide for fixation in a fixative solution (3 ethanol: 1 glacial acetic acid) overnight and stained with $1 \%$ orcein in $45 \%$ acetic acid. Stained oocytes

\section{Gene expression evaluation:}

RNA isolation was executed from each subgroup using easy-RED total RNA extraction kit (according to the procedure described by the manufacturer Cat.No.17063, iTRON Biotechnology Company, Korea ) and immediately used for reverse transcription (RT) using the PCR Sigma (Thermo Fisher Scientific Inc.): Revert Aid First Strand cDNA Synthesis Kit (Cat. No. K1691, USA).

\section{Semi-quantitative RT .PCR:}

The $1^{\text {st }}$ strand cDNA ( $2 \mathrm{ug}$ ) from different subgroups were used as template for PCR with a pair of specific primers. The sequences of specific primers and product sizes are listed in Table (1). PCR amplification was performed in a total reaction volume of $25 \mathrm{ml}$ containing $1 \mu \mathrm{l}$ of cDNA template, $10 \mu \mathrm{mol} / 1$ forward and reverses primers, $10 \mathrm{~m} \mathrm{~mol} / \mathrm{l}$ of dNTP mix, 10x PCR buffer and 2 units of Taq 
Gold polymerase. PCR conditions were: 1 cycle $\left(94{ }^{\circ} \mathrm{C}\right.$ for $\left.4 \mathrm{~min}\right), 35$ cycles $\left(94{ }^{\circ} \mathrm{C}\right.$ for $45 \mathrm{~s}, 56{ }^{\circ} \mathrm{C}$ for $45 \mathrm{~s}, 72{ }^{\circ} \mathrm{C}$ for $90 \mathrm{~s}$ ) for GAPDH and 1 cycle ( $95 \mathrm{C}$ for $4 \mathrm{~min}$ ), 35 cycles $\left(95^{\circ} \mathrm{C}\right.$ for $30 \mathrm{~s}, 55^{\circ} \mathrm{C}$ for $30 \mathrm{~s}, 72{ }^{\circ} \mathrm{C}$ for $45 \mathrm{~s})$ for $\mathrm{Cx} 43,1$ cycle $\left(95{ }^{\circ} \mathrm{C}\right.$ for $\left.4 \mathrm{~min}\right), 35$ cycles $\left(95^{\circ} \mathrm{C}\right.$ for $30 \mathrm{~s}, 55^{\circ} \mathrm{C}$ for $30 \mathrm{~s}, 72{ }^{\circ} \mathrm{C}$ for $45 \mathrm{~s}$ ) for $\beta$-actin, 1 cycle $\left(95^{\circ} \mathrm{C}\right.$ for $4 \mathrm{~min}$ ), 35 cycles (95 ${ }^{\circ} \mathrm{C}$ for $30 \mathrm{~s}, 55^{\circ} \mathrm{C}$ for $30 \mathrm{~s}, 72{ }^{\circ} \mathrm{C}$ for $45 \mathrm{~s}$ ) for IGF2, and $72{ }^{\circ} \mathrm{C}$ for 7 min (Metabion international AG Lena-Christ-Stresse 44/I A-8215 Martinsried/ Deuschland). All PCR products ( $8 \mu \mathrm{l}$ of $25 \mu \mathrm{l}$ total reaction volume) were electrophoresed in agarose gels $(1.5 \%, \mathrm{w} / \mathrm{v})$ containing ethidium bromide and visualized over UV light.

\section{Statistical Analysis:}

It was carried out using SPSS version 17. Results were expressed as mean \pm SEM. Analysis of variance (one way ANOVA) followed by Duncan' test were used to determine whether there were significant differences among the groups. Differences were considered significant when $\mathrm{P}$ values were less than 0.05 .

Table (1): Primers used for Real-Time PCR experiments to amplify studied genes

\begin{tabular}{|c|c|c|c|}
\hline $\begin{array}{l}\text { Genes and sequence } \\
\text { reference (GenBank } \\
\text { accession no.) }\end{array}$ & Primer sequences & $\begin{array}{l}\text { Size of PCR } \\
\text { product (bp) }\end{array}$ & $\begin{array}{l}\text { Annealing } \\
\text { temperature }\end{array}$ \\
\hline $\begin{array}{l}\text { GAPDH } \\
(\text { NM_001034034) }\end{array}$ & $\begin{array}{l}\text { F- TGA CCC CTT CAT RGA CCT TC } \\
\text { R- TAC TCA GCA CCA GCA TCA CC }\end{array}$ & 172 & 56 \\
\hline Cx43 (J 05535) & $\begin{array}{l}\text { F -GGG AAA GAG CGA TCC TTA CCA CAC } \\
\text { TAC CAC R -CCA CCT CCA ATG AAA CAA } \\
\text { AAT GAA CAC CTA }\end{array}$ & 164 & 55 \\
\hline$\beta$-actin (NM_001101) & $\begin{array}{l}\text { F- CGT GAG AAG ATG ACC CAG ATC A } \\
\text { R-GGG ACA GCA CAG CCT GGA T }\end{array}$ & 162 & 55 \\
\hline IGF2 (X53553) & $\begin{array}{l}\text { F -TCT ACT GCC GAC CAT CCA } \\
\text { R -TTC GGA AGC AAC ACT CTT CCA }\end{array}$ & 204 & 55 \\
\hline
\end{tabular}




\section{RESULTS}

The highest response $(76.84 \%)$ in term of the percentage the good oocytes was recorded in G3 suggesting the beneficial effect of ECS on maturation of buffalo oocytes. However the percentages of the good oocytes were $53.61 \%$ and $56.12 \%$ in $\mathrm{G} 2$ and G1 respectively.

Addition of serum to TCM-199 maturation medium significantly improved the nuclear maturation rate (MII stage) of G2 at $\mathrm{P}<0.05$ and $\mathrm{G} 3$ at $\mathrm{P}<0.01$ compared with $\mathrm{G1}$ (control). Moreover, the type of serum affected nuclear maturation rate as indicated by significant $(\mathrm{P}<0.05)$ increase in G3 compared with G2.Also, serum addition significantly decreased the percentages of intermediate stages in G3 at $\mathrm{P}<0.01$ and in $\mathrm{G} 2$ at $\mathrm{P}<0.05$ compared with $\mathrm{G} 1$ as well as the degenerated oocytes was high $(\mathrm{P}<0.05)$ in $\mathrm{G} 1$ compared with either G3 and G2( Table,2).

Expression of GAPDH, CX43, IGF II and $\beta$ - Actin genes were not differed among the three studied groups except CX43 is not expressed in FO subgroup in G1(Figure 1).

Table (2): Effect of serum addition to maturation medium on both oocyte expansion quality and nuclear maturation of IVM of buffalo oocytes

\begin{tabular}{|c|c|c|c|c|c|c|c|c|c|}
\hline \multirow{2}{*}{$\begin{array}{l}\text { Maturation } \\
\text { indices }\end{array}$} & \multicolumn{3}{|c|}{ G1 $(\mathrm{X} \pm \mathrm{SE}) \%$} & \multicolumn{3}{|c|}{ G2 $(\mathrm{X} \pm \mathrm{SE}) \%$} & \multicolumn{3}{|c|}{ G3 $(\mathrm{X} \pm \mathrm{SE}) \%$} \\
\hline & $\begin{array}{c}\text { GO } \\
n=165\end{array}$ & $\begin{array}{c}\text { FO } \\
n=129\end{array}$ & $\begin{array}{c}\text { Total } \\
N=294\end{array}$ & $\begin{array}{c}\text { GO } \\
n=267\end{array}$ & $\begin{array}{c}\text { FO } \\
n=231\end{array}$ & $\begin{array}{c}\text { Total } \\
\mathrm{N}=498\end{array}$ & $\begin{array}{c}\text { GO } \\
n=219\end{array}$ & $\begin{array}{c}\text { FO } \\
n=66\end{array}$ & $\begin{array}{c}\text { Total } \\
\mathrm{N}=285\end{array}$ \\
\hline DO & $6.6 \pm 5.87$ & $22.4 \pm 6.78 *$ & $13.4 \pm 4.69^{\mathrm{a}}$ & $8.5 \pm 4.80$ & $26.4 \pm 5.25^{*}$ & $16.6 \pm 5.01^{\mathrm{a}}$ & $0.0 \pm 0.00$ & $22.5 \pm 8.31 *$ & $7.5 \pm 4.79^{\mathrm{b}}$ \\
\hline GV & $11.1 \pm 3.72$ & $10.3 \pm 4.30$ & $4.4 \pm 2.56$ & $5.9 \pm 3.04$ & $6.0 \pm 3.33$ & $6.0 \pm 2.41$ & $8.8 \pm 3.72$ & $8.3 \pm 5.27$ & $8.6 \pm 2.97$ \\
\hline GVBD & $7.2 \pm 3.96$ & $14.0 \pm 4.58$ & $10.1 \pm 4.01$ & $7.3 \pm 3.24$ & $2.5 \pm 3.54$ & $5.1 \pm 2.07$ & $3.7 \pm 3.96$ & $5.0 \pm 5.60$ & $4.1 \pm 2.05$ \\
\hline Inter.S & $29.1 \pm 5.13$ & $38.2 \pm 5.13 *$ & $33.0 \pm 4.77^{\mathrm{a}}$ & $18.1 \pm 4.18$ & $29.9 \pm 4.58 *$ & $23.5 \pm 3.43^{b}$ & $8.6 \pm 5.13$ & $22.5 \pm 7.25^{*}$ & $13.2 \pm 3.76^{\mathrm{c}}$ \\
\hline MII & $57.2 \pm 7.07 * *$ & $15.1 \pm 8.16$ & $39.1 \pm 9.36^{\mathrm{c}}$ & $60.2 \pm 5.77 * *$ & $35.2 \pm 6.32$ & $48.8 \pm 6.35^{\mathrm{b}}$ & $78.9 \pm 7.07^{* * * * *}$ & $41.7 \pm 9.99$ & $66.5 \pm 8.35^{\mathrm{a}}$ \\
\hline
\end{tabular}

$\mathrm{DO}=$ Degenerated ooctes $\mathrm{GO}=$ good expanded oocyte $\mathrm{FO}=$ fair expanded oocyte $\mathrm{GV}=\mathrm{Germinal}$ vesicle stageGVBD= Germinal vesicle breakdown stage $\quad$ Inter.S= Intermediate stages $\quad$ MII= Metaphase-II stage

Figures carry superscript $\mathrm{a} \& \mathrm{~b}$ or $\mathrm{b} \& \mathrm{c}$ within the same row are significantly different at $\mathrm{P}<0.05$

Figures carry superscript a \& $\mathrm{c}$ within the same row are significantly different at $\mathrm{P}<0.01$

Figures carry superscript $(* *)$ within the same row and the same group are significantly different at $\mathrm{P}<0.01$

Figures carry superscript $(*)$ within the same row and the same group are significantly different at $\mathrm{P}<0.05$ 
Fig. (1): Genes expressions associated with different treatments:

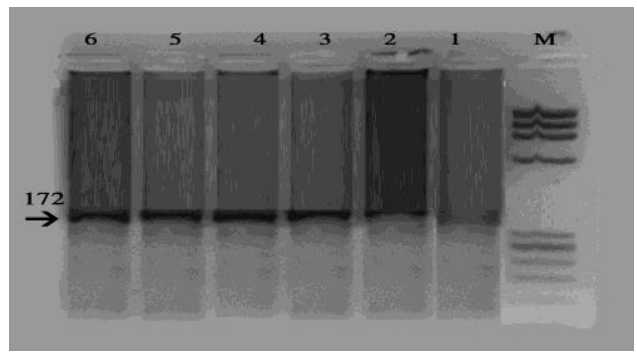

GAPDH

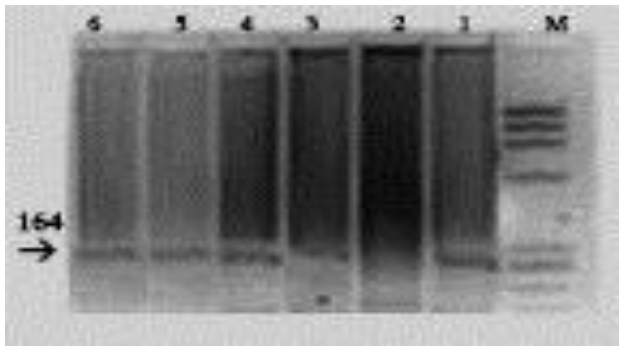

CX 43

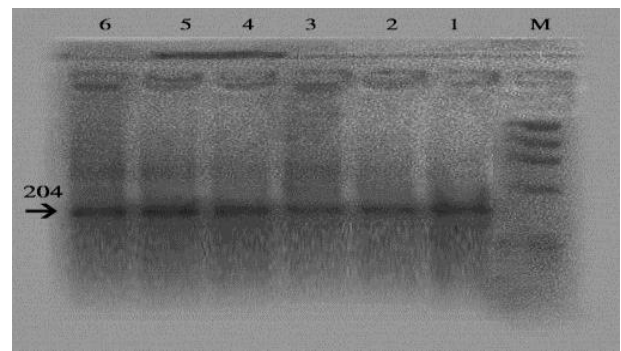

IGF II

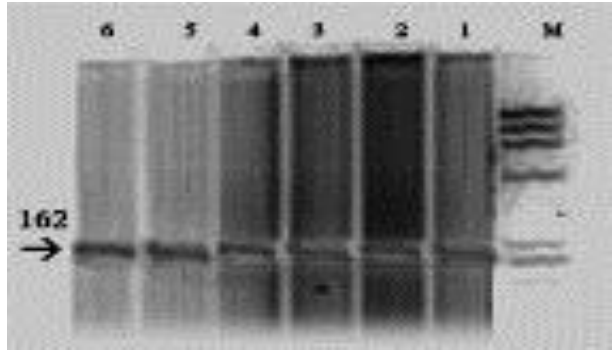

B-actin

M= Marker 1- Good expanded oocytes in serum free group, G1 2- Fair expanded oocytes in serum free group, G1 3- Good expanded oocytes in FCS subgroup,G2 4- Fair expanded oocytes in FCS subgroup, G2 5- Good expanded oocytes in ECS subgroup,G3 6- Fair expanded oocytes in ECS subgroup, G3

\section{DISCUSSION}

Supplementing maturation medium TCM-199 with blood sera in both G3 and G2 improved the maturation rate of buffalo oocytes compared to G1. This result agrees with the finding of Sagirkaya et al. 2004 and Hannelore et al., 2008 who found that Estrus cow serum improves rate of maturation and the blastocyst formation compared to the use of fetal bovine serum. Addition of serum to culture medium may affect not only the oocyte maturation and developmental potential of embryos but also, the gene expression pattern and apoptotic index (Rizos 
et al.,2003). Manipulation of the culture medium composition may modulate global gene expression and improve the overall efficiency of this technique (Watson et al., 2000; Lonergan et al., 2003 and María et al., 2013). Oocytes that had good cumulus expansion was accompanied with high nuclear maturation rate, M II $(\mathrm{P}<0.01)$ than fair ones. This could be explained in the light of the fact that the cumulus cells play an important role in regulating oocyte maturation and meiotic progression (Vozzi et al., 2001; Ward et al., 2002; Kakkassery et al..2010 and Xiang et al., 2010). So, Co-culturing COCs and denuded oocytes (Dos) may be an effective culture system for both intact COCs and immature Dos ( Dey et al,.2012). Qualitative expression of studied genes (GAPDH, CX43, IGF II and $\beta$ - Actin) was not differed except CX43 gene, which was not expressed in FO when serum was absent during IVM. Herve et al., 2008 and Laws et al., 2008 concluded that gap junctions are thought to play a crucial role in regulating cell growth and development in various tissues, including ovaries. The improved maturation rate as indicated by significant increase in MII and decrease in both degenerated and intermediate stages in oocytes cultured on serum supplemented TCM-199 may be attributed to the fact that serum induced expression of CX43 gene. Pandey et al., 2009 found that expressions of genes (Cx43, GDF 9, FGF-4 and Fibronectin) is positively correlated with cumulus expansion and polar body extrusion and presence of serum in the culture medium alters the expression of genes (Wrenzycki et al., 1999), particularly genes involved in lipid metabolism (Plourdea et al., 2012). Connexin $43(\mathrm{Cx} 43)$ absence disrupts progression of follicles beyond primary stages in transgenic mouse ovaries (Bolamba et al., 2002) and it expressed in immature and in vitro matured oocytes but in 
embryos it was detected up to morula stage only (Mishra et al., 2010), the relative abundance of $\mathrm{Cx} 43$ could be used as a marker of developmental potential for embryos derived from oocytes. Level of Cx43 transcript was reported to be greater in embryos derived from oocytes with greater developmental competence compared with those derived from oocytes with less developmental competence (Nemcova et al., 2006).

Variation in GAPDH expression at the maturation stage of in vitro produced oocytes may be attributed to the type of maturation media which affecting the stability and turn over rate of mRNA (Feuerstein et al.,2007).

It could be concluded that addition of bovine sera especially estrus cow serum enhance in vitro maturation of the buffalo oocytes and genes expression (GAPDH, IGF2, $\beta$-actin and CX43) and Further studies is needed to enhance the expression of CX43 gene which might help in increasing maturation rate.

\section{REFERENCES}

- Blanco MR, Simonetti L (2002): Morphological survival of immature and in vitro matured bovine oocytes after cryopreservation in Solutions containing different protein concentrations. In vitro Cell Dev. Biol., 38: 19A, V-1004

- Bolamba D., Floyd A. A., McGlone J. J., and Lee V. H. (2002): Epidermal Growth Factor Enhances Expression of Connexin 43 Protein in Cultured Porcine Preantral Follicles. Biology of reproduction $67,154-160$ 
- Dey S.R., Deb G.K., Ha A.N., Lee J.I., Bang J.I., Lee K.L., Kong I.K. (2012): Coculturing denuded oocytes during the in vitro maturation of bovine cum $\mu$ lus oocyte complexes exerts a synergistic effect on embryo development. Theriogenology 77 1064-1077

- Feuerstein, P., Cadoret, V., Dalbies, T. R., Guerif, F., Bidault, R. and Royere, $D$. (2007): Gene expression in human cumplus cells: one approach to oocyte competence. Hum. Reprod., 22: 3069-3077

- Gershon, E., Plaks, V. and Dekel, N. (2008): Gap junction in ovary: Expression,localization and function.Mol.Cell.Endocrinol.,282:18-25.

- HANNELORE ALM, HELMUT TORNER, WILHELM KANITZ, KNUT ROSCHLAU(2008): Influence of oocyte recovery method, in vitro fertilization method and serum source on embryonic development of in vitro matured bovine oocytes.Arch. Tierz., Dummerstorf 51, 3, 224-234

- Herve, J.C., Derangeon, M., Theveniau-Ruissy, M., Miquerol, L., Sarrouilhe, D. and Gros, D. (2008): Connexins and junctional channels. Roles in the spreading of cardiac electrical excitation and heart development. Pathol. Biol. (Paris)., 56: 334-341.

- Kakkassery M.P., Vijayakumaran V. and Sreekumaran T. (2010): Effect of cumulus oocyte complex morphology on in vitro maturation of bovine oocytes. Vet. Anim.Sci. $41: 12-17$

- Kastrop PM, Bevers MM, Destree OH, Kruip TA. (1991): Protein synthesis and phosphorylation patterns of bovine oocytes maturing in vivo. Mol Reprod Dev. 29:271-5. 
- Kim MK, Fibrianto YH, Oh HJ, Jang G, Kim HJ, Lee KS, Kang SK, Lee BC, Hwang WS (2005): Effects of estradiol-17beta and progesterone supplementation on in vitro nuclear maturation of canine oocytes. Theriogenology 63, 1342-1353.

- Laws, M.J., Taylor, R.N., Sidell, N., DeMayo, F.J., Lydon, J.P., Gutstein, D.E., Bagchi, M.K. and Bagchi, I.C. (2008): Gap junction communication between uterine stromal cells plays a critical role in pregnancy-associated neovascularization and embryo survival. Develop. 135: 2659-2668.

- Lonergan P, Gutierrez-Adan A, Rizos D, Pintado B, de la Fuente J, Boland MP. (2003): Relative messenger RNA abundance in bovine oocytes collected in vitro or in vivo before and $20 \mathrm{~h}$ after the preovplatory luteinizing hormone surge. Mol Reprod Dev 66: 297-305.

- María E. Arias, Pablo J. Ross and Ricardo N. Felmer (2013): Culture medium composition affects the gene expression pattern and in vitro development potential of bovine somatic cell nuclear transfer (SCNT) embryos. Biol Res 46: 452-462

- Mishra A, Taru Sharma G., Sai Kumar G. (2010): Expression Profile of Connexin 43 and Poly A Polymerase Genes in Buffalo (Bubalus bubalis) Oocytes and Developing Embryos Produced in vitro J. Appl. Anim. Res. 38 : 29-32.

- Nemcova L., Machatkova M., Hanzalova K., Horakova J., KankaGene J. (2006): expression in bovine embryos derived from oocytes with different developmental competence collected at the defined follicular developmental stage. Theriogenology 65, 1254-1264. 
- Pandey A, Gupta SC, Singh N, Rana JS and Gupta N (2010): Efficiency of SCNT Buffalo (Bubalus bubalis) Embryos in Different Culture Medium and Analysis of mRNA Expression of Insulinlike Growth Factors During Embryogenesis. Reprod Dom Anim 45, 786-795.

- Pandey A. \& Gupta N. \& Gupta S.C. (2009): Improvement of in vitro oocyte maturation with lectin supplementation and expression analysis of Cx43, GDF-9, FGF-4 and Fibronectin mRNA transcripts in Buffalo (Bubalus bubalis). J Assist Reprod Genet 26:365-371.

- Plourdea D., Vigneaultb Ch., Lemaya A., Bretona L., Gagnéa D., Laflammea I., Blondinb P., Roberta C. (2012): Contribution of oocyte source and culture conditions to phenotypic and transcriptomic variation in commercially produced bovine blastocysts. Theriogenology 78, 116-131.

- Rappolee DA, Sturm KS, Behrendtsen O, Schultz GA, Pedersen RA, Werb Z, (1992): Insulin-like growth factor II acts through an endogenous growth pathway regulated by imprinting in early mouse embryos. Genes Dev 6, 939-952.

- Rizos D, Gutierrez-Adan A, Perez-Garnelo S, dela FJ, Boland MP, Lonergan P,(2003):Bovine embryo culture in the presence or absence of serum: implications for blastocyst development, cryotolerance, and messenger RNA expression.Biol Reprod 68, 236-243.

- Sagirkaya H, Yagmur M, Nur Z, Soylu MK (2004): Replacement of fetal calf serum with synthetic serum substitute in the in vitro maturation medium: Effects on maturation, fertilization and subsequent development of cattle oocytes in vitro. Turk. J. Vet. Anim. Sci., 28: 779-784. 
- Shamiah, Sh. M. (2004): Studies on in vitro fertilization in Egyptian buffaloes. Ph.D. Thesis, Faculty of Agriculture, Mansoura University, Egypt.

- Sirard MA, Florman HM, Leibfried-Rutledge ML, Barnes FL, Sims ML, First NL.(1989): Timing of nuclear progression and protein synthesis necessary for meiotic maturation of bovine oocytes. Biol Reprod.40:1257-63.

- Sirard, M. A. (2001): Resumption of meiosis: mechanism involved in meiotic progression and its relation with developmental competence. Theriogenology 55:1241-1254.

- Song HJ, Kang EJ, Maeng GH, Ock SA, Lee SL, Yoo JG, Jeon BG, Rho GJ (2010): Influence of epidermal growth factor supplementation during in vitro maturation on nuclear status and gene expression of canine oocytes. Research in Veterinary Science 91, 439-445.

- Vanderhyden, B. C., E. E. Telfer and J. Eppig. (1992): Mouse oocytes promote proliferation of granulosa cells from preantral and antral follicles in vitro. Biol. Reprod. 46:1196-1204.

- Vikash Chandra, G. Sai Kumar, G. Taru Sharma (2011): Temporal expression pattern of insulin-like growth factors (IGF-1 and IGF-2) ligands and their receptors (IGF-1R and IGF-2R) in buffalo (Bubalus bubalis) embryos produced in vitro Livestock Science 135 225-230.

- Vozzi, C., A. Formenton, A. Chanson, A. Senn, R. Sahli, P. Shaw, P. Nicod, M. Germond and J. A. Haefliger. (2001): Involvement of connexin 43 in meiotic maturation of bovine oocytes. Reproduction 122:619-628. 
- Ward, F., B. Enright, D. Rizos, M. Boland and P. Lonergan. (2002): Optimization of in vitro bovine embryo production: Effect of duration of maturation, length of gamete co-incubation, sperm concentration and sire. Theriogenology 57:2105-2117.

- Watson AJ, De Sousa P, Caveney A, Barcroft LC, Natale D, Urquhart J, et al. (2000): Impact of bovine oocyte maturation media on oocyte transcript levels, blastocyst development, cell number, and apoptosis. Biol Reprod. 2:355-64.

- Wrenzycki C, Herrmann D, Carnwath JW, Niemann H, (1999): Alterations in the relative abundance of gene transcripts in preimplantation bovine embryos cultured in medium supplemented with either serum or PVA. Molecular Reproduction \& Development, $53,8-18$.

- Wrenzycki C, Herrmann D, Lucas-Hahn A, Korsawe K, Lemme E, Niemann H. (2005): Messenger RNA expression patterns in bovine embryos derived from in vitro procedures and their implications for development. Reprod Fertil Dev;17:23-35.

- Xiang Z.F, Zhang J.Z., Li X.B., Xie H.B. and Wang Q.H. (2010): Comparison of Gene Expression between Cumulus Oocyte Complexes and Naked Oocytes by Suppression Subtractive Hybridization in Swine. Asian-Aust.J.Anim.Sci.Vol.23,No.1:17-24. 
تأثثير إضافة السيرم البقرى الى بيئة انضاج البويضات الجاموسى معطيا على كل من

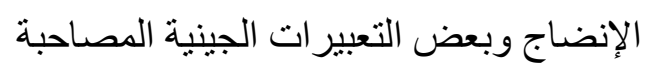

\section{شريف محمد شامية ، عبد الجواد خليفة قادوم ، أيمن محمد فؤاد \\ معهل بحوث النتاج الحيوانى - مركز البحوث الزراعية- مصر}

لاستبيان تأثير اضافة السيرم البقرى الى بيئة إنضاج بويضات الجاموس معمليا على معدل الإنضاج و كذلك على تعبير بعض الجينات ذات الصلة فقد جمعت 1149 بويضة جاموسى غير ناضجة جيدة المظهر ( بويضات محاطة بخلايا وسادية ومتجانسة البلازما الخلوية ) و زراعتها عشوائيا على حسب نوع السيرم المضاف الى بيئة الزراعة الخاصة بنمو البويضات معمليا :المجموعة الأولى لئى

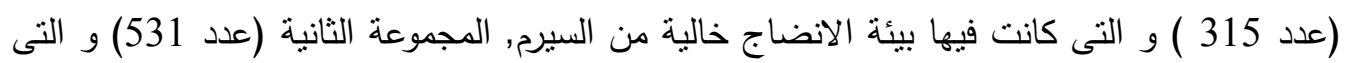
أضيف إليها سيرم العجول الجنينى بواقع 10\% بويضة والمجموعة الثالثة (عدد 303) و النى أضيف إليها سيرم البقر الثبقى بواقع 10\%. قشمت البويضات بعد انضاجها فى كل مجموعة على حسب مظهرها من تمدد الخلايا الوسادية وتجانس السيتوبلازم الى بويضات جيدة التمدد وبويضات ضعيفة

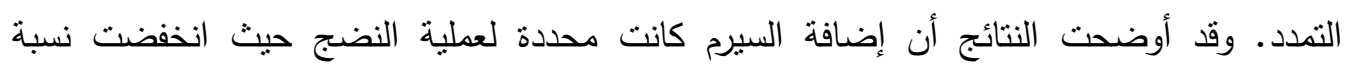
الانضاج فى البيئة النى لم يضف اليها السيرم بشكل معنوى وكذلك أوضحت النتائج ان التعبيرات الجينية المختلفة (GAPDH, CX43, IGF II and $\beta$ - Actin) كانت واضحة فى جميع المجموعات فيما عدا مجموعة واحدة (البويضات ضعيفة التمدد فى غياب السيرم) حيث لم نظهر تعبير جين CX43 وأن البويضات المحاطة بالخلايا الوسادية المتمددة أظهرت نضجا عاليا بمعنوية احصائية (P<0.01) ) خلافا عن البويضات التى فقدت خلاياها الوسادية او انكمت فيها البلازما الخلوية. وبناء على النتائج يمكن ان نخلص بأن اضافة السيرم الى بيئة النمو وخاصة سيرم دم البقر الثبقى يزيد كل من نسبة انضاج البويضات الجاموسى وكذلك التعبيرات الجينية المصاحبة وأن اختيار البويضات على أساس الخلايا الوسادية المحيطة فقط يعد غير كاف ولكن ضبط بيئة الانضاج وإضافة المواد التى تحفز وتسرع من أداء التعبيرات الجينية وخاصة جين CX43 تعد هى الامل فى زيادة نسب الانضاج. 